\title{
A IMPRENSA ESCRITA COMO AFIRMAÇÃO DO DISCURSO DOCENTE: PRÁTICAS PARA O ENSINO DE HISTÓRIA
}

\author{
THE WRITTEN PRESS AS AN AFFIRMATION OF THE TEACHING DISCOURSE: \\ PRACTICES FOR HISTORY TEACHING
}

\author{
Regina Beatriz Guimarães Neto ${ }^{1}$ \\ Jonathas Duarte Oliveira de Souza ${ }^{2}$
}

\begin{abstract}
RESUMO: Este trabalho discute a utilidade de jornais impressos para o Ensino da História sobre a Ditadura Militar (1964 - 1985). Sem procurar se constituir um manual delimitado de técnicas, faz uma breve apreciação da prática docente para o Ensino de História e debate o atual modelo, considerado relativamente pobre de atributos que caracterizam o regime de 1964 como uma ditadura. Reflete a dimensão de fontes históricas para o Ensino de História, atrelada à interpretação dos textos em perspectiva multidisciplinar, utilizando neste o Jornal do Brasil (RJ). Assim, inspirando-nos em Foucault, procuramos analisar as matérias da imprensa que podem ser utilizadas na escola, a fim de desnaturalizar os discursos que se multiplicam a partir de lugares institucionais.
\end{abstract}

Palavras-chave: Ensino de história; Imprensa escrita; Análise do discurso; Ditadura militar.

\begin{abstract}
This paper discusses the value of printed newspapers for history teaching about the Military Dictatorship (1964-1985). This paper does not seek to be a delimited manual of techniques, but it makes a brief appreciation of the teaching practice in History teaching and debates the current model, considered relatively poor of attributes that characterize the regime of 1964 as a dictatorship. It reflects on the dimension of historical sources for history teaching, linked to text interpretation in a multidisciplinary perspective, using the Jornal do Brasil (RJ). Thus, drawing inspiration from Foucault, we try to analyze the press articles that can be used in school, in order to denaturalize discourses that multiply through institutional places.
\end{abstract}

Keywords: History teaching. Written press. Discourse analysis. Military Dictatorship.

\footnotetext{
1 Professora Adjunto IV do Departamento de História e do Programa de Pós-Graduação em História da Universidade Federal de Pernambuco. Professora Associada I aposentada da Universidade Federal de Mato Grosso. Professora Colaboradora do Programa de PósGraduação em História da Universidade Federal de Mato Grosso. Possui Bolsa produtividade do CNPq.

2 Licenciado em História (2018) pela Universidade Federal de Pernambuco (UFPE) e mestrando pelo Programa de Pós-graduação em História da Universidade Federal de Pernambuco (PPGH/UFPE), linha de pesquisa - Cultura e Memória.
} 


\section{Introdução}

O desenvolvimento deste trabalho é orientado por inquietações que surgiram ao longo da minha formação como pesquisador e professor de História. Durante a trajetória acadêmica, um dos fios condutores para minhas investigações foi analisar os mecanismos que levam parte da sociedade a naturalizar o exercício arbitrário e abusivo do poder. Desta forma, realizei pesquisas ${ }^{3}$ que tiveram por objetivo compreender como funcionava o processo de subjetivação/sujeição em relação à dominação a partir de discursos que surgiam em lugares institucionais pretensamente inofensivos, como a escola e a imprensa.

Em razão disso, justificamo-nos pelo pensamento de Marc Bloch (2001). De acordo com este autor, a História precisar ter um problema a responder, e este surge a partir do presente. Por outro lado, para Reis (2006), a História deve produzir um movimento contrário ao do progresso, este pensado em direção ao futuro, como a marcha inevitável da humanidade ${ }^{4}$. Torna-se necessário debater as racionalidades que se querem naturais; a escrita deve ser "contra-mola", produzir movimento que seja de desprogramação da ordem que se quer natural, para que se resguardem as tensões entre passado e presente.

Esta preocupação para a escrita da História não é mero capricho intelectual. A busca pela descontinuidade na História ${ }^{5}$, inspirada por Nietzsche (2008), Foucault (2008) e Farge, (2011), faz parte de um movimento epistemológico que rompe com o modelo cientificista, francês ou

\footnotetext{
3 A partir dos resultados das minhas pesquisas no âmbito do Programa Institucional de Bolsas de Iniciação à Docência 2014-2016 (PIBID), sobre práticas docentes para o Ensino de História, e do Programa Institucional de Bolsas de Iniciação Científica (PIBIC) 20172018, sobre o funcionamento da imprensa como dispositivo político para o governo militar, período do general presidente Garrastazu Médici.

4 Ver Benjamin(1985).

5 "A história será 'efetiva' na medida em que ela reintroduzir o descontínuo [...]. Ela não deixará nada abaixo de si que teria a tranquilidade asseguradora da vida ou da natureza; ela não se deixará levar por nenhuma obstinação muda a um fim milenar. Ela aprofundará aquilo sobre o que se gosta de fazê-la repousar e se obstinará contra sua pretensa continuidade." (FOUCAULT, 2008, p. 27-28)
} 
alemão, do século XIX. O século XIX, na historiografia, é caracterizado por uma demanda na escrita marcada pela exaltação do poder centralizado no Estado como indicador do êxito - europeu - do desenvolvimento humano ao longo da sua marcha. Essa ideia de progresso funciona como justificativa das nações imperialistas para invadir outros territórios e submeter suas populações à dominação, mas sob a roupagem moderna da democracia, progresso e paz.

As consequências deste discurso filosófico da modernidade são amplamente debatidas em âmbito acadêmico. Fatos como as bombas atômicas na Segunda Guerra Mundial, que levaram à morte milhares de pessoas, demonstram os limites aos quais o discurso do progresso submeteu as populações. Esses limites, curiosamente, justificam-se na retórica do inevitável, do bem comum e da defesa de todos, como demonstra Farge $(2011)^{6}$.

A experiência ora citada não é a única que anuncia o fracasso do projeto moderno ${ }^{7}$. Contando com a leitura de Hartog (2013), a experiência moderna também frustrou as populações com o avanço industrial, que ao invés de trazer oportunidades de trabalho para todos, recrudesceu a ordem de exploração e não deu conta de explicar os motivos pelos quais as populações permanecem sendo submetidas a condições desumanas de exploração e pobreza.

Ao inscrever recortes ao tema da "História Iluminista", este trabalho reflete o uso de excertos de jornais, junto aos livros didáticos, para desnaturalizar a ação discursiva da imprensa, além de pensar como as representações jornalísticas sobre a Ditadura Militar (1964-1985) ${ }^{8}$ ratificam visões modernas de trabalho, progresso e sujeição política. Desde já importa dizer que este trabalho não visa indicar um corpo de normas, mas sim reflexões para o desenvolvimento da prática docente.

É comum que o currículo escolar secrete os interesses dos que exercem o poder, pois a escrita e transmissão da História é feita por quem

\footnotetext{
6 Veja "Da Guerra" e "Da opinião" Farge (2011).

7 Ver Habermas (2000, p. 5-11,) e prefácio.

8 Com amplo apoio de setores civis (para alguns empresariais). A generalização é utilizada por reconhecer um amplo debate em torno da conceituação deste período, mas que não é objetivo deste trabalho.
} 
vence. Observa-se, nesta racionalidade, a instrumentalização de instituições públicas para corroborar visões selecionadas do mundo. Nos termos de Walter Benjamin (1985, p. 225), nas Teses sobre o conceito de História, é possível dizer que a escola inspira empatia para com os sujeitos vencedores, por mobilizar discursos que não encarnem a pesada materialidade do regime militar de 1964-1985.

A imprensa, por sua vez, reúne práticas discursivas que naturalizam ações governamentais e produzem uma continuidade com determinada forma de ver o mundo. Em resumo, a imprensa, nas suas formas de dizer, e a escola, na medida em que conserva determinada grade curricular, contribuem para ser agentes multiplicadores das expectativas governamentais, baseados nos seus lugares de poder e supostos discursos imparciais.

Assim, é parte deste trabalho refletir sobre o uso da imprensa para ensinar a História da Ditadura Militar, pautada no método da descontinuidade. Apoiado pelas sugestões teórico-metodológicas de Faria (2004, 2009) e Faria e Zanchetta Junior (2005), há a possibilidade de pensar esses dois lugares - imprensa e escola - juntos, de forma a desnaturalizar a ação discursiva da imprensa com base na prática docente e mostrar seu papel social de produção de verdades e memória histórica. Desse modo, reflete-se o ensino de forma multidisciplinar, a desenvolver competências de interpretação, além de respeitar a especificidade temporal da velocidade da comunicação, ao utilizar jornais para ensinar História.

Uma breve genealogia do saber escolar permite dizer que esta instituição carrega uma História mais complexa do que aparenta o enunciado de democratização do saber. De acordo com os Parâmetros Curriculares Nacionais (PCN's), o Ensino de História pode ser caracterizado a partir de dois momentos: o primeiro no início do século XIX, com a introdução da História no currículo. O segundo, a partir das décadas de 30 e 40 do século $X X$, orientado por uma política nacionalista $e$ desenvolvimentista (BRASIL, 1998, p. 19), assinala a preocupação com uma "genealogia da nação". 
Assim, ensinar História era percebido como realizar a transmissão dos conteúdos estabelecidos nos livros e dentro do programa oficial, julgando que aprender História se reduzia a memorizar e a transcrever as lições (ARRIADA; VALLE; CLARO, 2011, p. 62). Esse foi um tempo de exaltação da "História Nacional", cuja missão era a de integrar o povo brasileiro à moderna civilização ocidental e ensinar os pressupostos de ser um bom cidadão (FONSECA, 2003, p. 56). Seus conteúdos deveriam enfatizar as tradições de um passado homogêneo, com feitos gloriosos e personagens que lutaram pela defesa do território e da unidade nacional.

No período da Ditadura Militar, a questão do Ensino de História envereda por outros caminhos. O ensino de História e Geografia foi preterido em favor dos chamados Estudos Sociais, que manipulavam o que é "útil" ou "inútil" à população, objetivando justificar o projeto nacional organizado pelo governo militar de 1964. Do mesmo modo, como em outros momentos, houve a seleção de fatos, de histórias "corretas" a contar, que se assentam nas expectativas de implementação da dominação pela escola, preconizadas pelos currículos disciplinares.

Após o fim da Ditadura e o retorno das disciplinas específicas, os professores passaram a relatar a impossibilidade de transmitir nas aulas o conhecimento de todos os tempos da História da humanidade, daí se passou a buscar alternativas às práticas simplificadoras da História oficial (ARRIADA; VALLE; CLARO, 2011, p. 64).

As pesquisas de fins do século $X X$, no campo da Educação, demonstraram a importância de adotar metodologias ativas para o Ensino de História, como a diversificação das fontes documentais. Esta metodologia também se explica por ser uma alternativa aos livros didáticos, pois embora sejam importantes instrumentos pedagógicos, são produtos de grupos sociais, que procuram perpetuar identidades e valores. Como diz Bittencourt, são

[...] um produto do mundo da edição que obedece à evolução das técnicas de fabricação e comercialização pertencentes à lógica do mercado. Como mercadoria ele sofre interferências variadas em seu processo de fabricação e 
comercialização. Em sua construção interferem vários personagens, iniciando pela figura do editor, passando pelo autor e pelos técnicos especializados dos processos gráficos, como programadores visuais, ilustradores (BITTENCOURT, 2009, p. 71).

Assim, nota-se que a prática docente deve buscar constantemente fontes que viabilizem o contato com a História, para que as aulas não fiquem presas num modelo, literalmente, industrializado; é também uma maneira de agregar autoridade ao discurso do historiador, além de atualizar constantemente o docente a partir da prática de pesquisa.

O resultado das idas e vindas sobre o Ensino da História ora citadas, na contemporaneidade, se expressa em uma disciplina fragmentária do ponto de vista negativo, atomizada e desconexa, pois não permite nem ao menos o desenvolvimento da ideia de sincronia do tempo, ou seja, que vários eventos/acontecimentos ocorram no mesmo momento, e que podem ser entrecruzados. A isto está ligado o modelo de crônica de fatos que, no caso do ensino da Ditadura Militar, não se preocupa com atributos conceituais, não problematiza aspectos do exercício abusivo do poder e do autoritarismo, que caracteriza o regime de 1964 como ditadura. Apenas descreve ações políticas encadeadas no tempo, sob um pano de fundo que tem como base explicativa o discurso do progresso. Isso faz ser comum que alunos saiam da Educação Básica sem saber definir conceitualmente o que é ditadura, fascismo, neoliberalismo, etc.

Percebe-se, assim, a instrumentalização do conhecimento histórico muito mais para cumprir a tabela formal curricular do que conhecer os fundamentos que caracterizam o período como uma ditadura. Um modelo informativo predomina na Educação Básica. Ou seja, não há uma preocupação em formar cidadãos conscientes e atuantes em favor dos direitos, mas sim a manutenção de uma ordem no pensamento que prevê a alienação, a naturalização de práticas políticas como a produção de violência no ordenamento jurídico e a introjeção de uma concepção autoritária da ordem. 
Importa dizer que a escola deve ser o lugar da integração entre o mundo e as comunidades, da diversidade e produção de saber, no entanto, ao insistir em trabalhar fatos específicos, em compartilhar determinadas perspectivas de mundo, segue multiplicando as expectativas dos sujeitos que exercem o poder. Desta forma, os jornais podem ser úteis na Educação Básica por constituírem uma fonte primária de informação e que possibilita a mediação com o resto da sociedade, tomando o professor como referencial (FARIA; ZANCHETTA JUNIOR, 2005, p. 11), além de sugerir novos caminhos para modernizar o eixo ensino-pesquisa em âmbito escolar.

De acordo com Faria (2009), os jornais podem ser utilizados a partir de diversas perspectivas e em faixas etárias diversas, que variam desde o Ensino Fundamental até o Médio. Em seus livros, recomenda atividades para os alunos que vão da análise dos títulos para desenvolvimento de competências de interpretação de texto, até discernir a importância que cada jornal dá a determinado fato. Suas reflexões também contemplam o questionamento do caráter privado dos jornais, pois há uma diferença entre os fatos ocorridos e as versões que são propagadas, cabendo ao professor estimular a criatividade da interpretação sobre o percurso das informações até chegar aos leitores (FARIA; ZANCHETTA JUNIOR, 2005, p. 15).

Em linhas gerais, os jornais são importantes por provocarem um esforço nos alunos a questionar a aparente objetividade do mundo que os cerca, levando-os a serem mais críticos com a sua realidade. É fundamental este tipo de exercício em tempos de globalização, no qual a produção de informações em tempo real tem imenso poder de formação de opiniões e pode se constituir "gatilho" para as ações. Nesta reflexão, o aprendizado de História contempla temas que permeiam a realidade dos alunos, relevante para superação da exclusão social, na construção da cidadania e na emancipação social e política dos sujeitos (FONSECA, 2003, p. 52).

Dito de outra forma, a imprensa é um mecanismo fundamental para a compreensão da História, pois

[...] é um registro da história no seu dia a dia. Mas uma 'história truncada, um mundo caótico', como observa Nicolau Sevcenko. Isto, entretanto, leva o aluno a adquirir a 
competência necessária para ordenar e compreender esse caos aparente. Para tanto, ele aprenderá a relacionar o passado com o presente, buscando as origens dos fatos e a refletir sobre as consequências daquilo que ocorre dia após dia, numa projeção da história para o futuro (FARIA; ZANCHETTA JUNIOR, 2005, p. 12).

Este tipo de fonte documental, anteriormente visto de forma depreciativa pelos historiadores, hoje tem recebido apreciação positiva e faz parte de uma parcela expressiva das pesquisas contemporâneas no campo da História, incluindo a esfera teórico-metodológica. Nomes como Maria Helena Capelato e Tania de Luca, integram produções reconhecidas sobre o uso desta fonte.

O levantamento apresentado por Tânia de Luca em "História dos, nos e por meio de periódicos" (2005), apresenta os temas para os quais esta fonte tem contribuído no âmbito da historiografia brasileira, destacando-se "O Bravo Matutino. Imprensa e Ideologia no jornal O Estado de São Paulo", de autoria de Maria Helena Capelato e Maria Lígia Prado (1980), tese na qual a única fonte histórica é o próprio jornal

[...] por entender-se a imprensa fundamentalmente como instrumento de manipulação de interesses e de intervenção na vida social; nega-se, pois, aqui, aquelas perspectivas que a tomam como mero "veículo de informações", transmissor imparcial e neutro dos acontecimentos, nível isolado da realidade político-social na qual se insere (CAPELATO; PRADO, 1980, p. 19 apud LUCA, 2005, p. 118).

Um importante trabalho que desnaturaliza o lugar institucional e de poder que se reserva a imprensa é feito por Meneses (2014). Esta autora apresenta o conceito de Operação Midiográfica, que acontece em dois momentos: a escritura de eventos na cena pública e a inscrição de acontecimentos na duração como marco para determinada sociedade (MENESES, 2014, p. 232-241). O primeiro momento se dá a partir da produção dos fatos: forças são empreendidas para captação dos sentidos dos ocorridos cotidianos; acontece o que pode ser visto como uma interdição da informação: ela é trabalhada, reformulada e contada da ótica 
de quem a interpreta. O segundo momento é o da inscrição do evento na duração, ou seja, a liberação do fato construído para a grande população que recebe estas informações como verdade, pelo lugar de poder dos jornais: são apresentados e naturalizados como opinião pública e imparcial.

Utilizando este arcabouço teórico para nossas pesquisas ${ }^{9}$, pudemos analisar a ação discursiva dos jornais na Ditadura Militar (1964-1985). Este regime não era classificado como uma Ditadura ou um golpe à democracia, mas uma Revolução. Esta produção discursiva associava-se ao apelo do universo simbólico da população, como se vê na matéria de 26/2/1970, do Jornal do Brasil, intitulada "Seleção se exibirá em homenagem à Revolução", na qual

Atendendo a um pedido do presidente Garrastazu Médici aos dirigentes da CBD, a Seleção Brasileira fará no próximo dia 31 de março, data em que se comemora mais um aniversário da Revolução de 64, um treino coletivo no Maracanã com os portões abertos. [...] (SELEÇÃO se exibirá em homenagem à Revolução. Jornal do Brasil, Rio de Janeiro, p. 26, 26 fev. 1970)

Além disso, também é passada a imagem de que o regime é democrático e nacionalista, realizando-se para o bem do povo brasileiro em geral. Na manchete "Missão Histórica", do mesmo jornal, no dia 31/10/1974, há uma matéria valorando positivamente as ações do governo

[...] e não tardou muito para estabelecer-se um saudável entendimento entre a nação e o líder que francamente reconheceu a situação crítica do país, e, no mesmo passo, propôs-se trabalhar pelo advento da plenitude democrática. [...] Entre tantas iniciativas encetadas a partir de um ano, bastaria lembrar as grandiosas obras públicas a que 0 governo se lançou com segurança. Uma delas, a Transamazônica, no contexto do Plano de Integração Nacional, responde sozinha a uma velha ânsia de situar o Brasil na escala de grandeza que ele há muito reclama. A conquista e a ocupação da Amazônia constituem todo um programa de governo e estão naturalmente destinadas a marcar época na história do encontro do país com o seu

\footnotetext{
9 PIBIC 2017-2018.
} 
destino e as suas responsabilidades (MISSÃO Histórica. Jornal do Brasil, Rio de Janeiro, p. 1, 31 out. 1974).

Estes trechos sinalizam a ação da imprensa como um importante dispositivo ${ }^{10}$ político que multiplica discursos e expectativas do governo através do compartilhamento de significados. De acordo com Capelato $(1988$, p. 21)

[...] a imprensa constitui um instrumento de manipulação de interesses e intervenção na vida social. Partindo desse pressuposto, o historiador procura estudá-lo como agente da história e captar o movimento vivo das ideias e personagens que circulam pelas páginas dos jornais. A categoria abstrata "imprensa" se desmistifica quando se faz emergir a figura de seus produtores como sujeitos dotados de consciência determinada na prática social.

Pensar o uso de jornais, como mostra este trabalho, também facilita construir a ideia da simultaneidade dos fatos. A política brasileira a partir de 1964, respeitava determinadas alianças que, no contexto internacional, correspondiam ao desenrolar da Guerra Fria ${ }^{11}$. Aspectos da polarização mundial ficam evidentes na reportagem "General vê Amazônia sob ameaça", 14/8/1971, Jornal do Brasil, na qual a partir da ideia de segurança nacional, a colonização da Amazônia se justifica:

O general Carlos Alberto afirmou hoje [...] que 'é necessário acelerar todas as providências que visem desenvolver $e$ integrar a Amazônia [...] para enfrentar a cobiça das potências estrangeiras, que triplicará com o Plano de Integração Nacional.'[...] O general Carlos Alberto, que integra a comitiva da Escola Superior de Guerra, acha que além da cobiça internacional, existe ainda o perigo da penetração do comunismo, impulsionado pelo Presidente Allende, do Chile, através da Bolívia [...] (GENERAL vê Amazônia sob ameaça. Jornal do Brasil, Rio de Janeiro, p. 4, 14 ago. 1971.).

10 Ver Revel (2005, p. 39).

11 Também é componente curricular da Educação Básica. 
A política governamental se arma de justificativas para classificar a Amazônia como passível de intervenção pela sua utilidade econômica e pela questão da segurança nacional. Desta forma, o governo realizaria o objetivo de todos os outros "brasileiros corajosos", representados na imagem dos bandeirantes ${ }^{12}$, de integrar o território para usufruir de seus potenciais agropecuários e de mineração, pois no discurso governamental, a Amazônia teria um grande potencial inexplorado, como explícito na reportagem "Delfim Netto defende a integração, 17/7/1970"

O ministro da fazenda, Sr. Delfim Netto, defendeu ontem no Congresso o Plano de Integração Nacional, como forma de mobilizar riquezas não aproveitadas e criar mercado para as indústrias do Norte e Nordeste, e afirmou que não haverá qualquer prejuízo para os programas de industrialização da Sudene (DELFIM Netto defende a integração. Jornal do Brasil, Rio de Janeiro, p. 1, 17 jul. 1970).

Associado a este discurso, observa-se o encorajamento da migração da população para a Amazônia, sob o discurso de Reforma Agrária. Lá haveria terra e um mercado de trabalho que poderia absorver a todos, resolvendo os conflitos agrários no Nordeste, ilustrado na reportagem "Famílias pernambucanas instalam-se na Amazônia", de 7/5/1971

O envio de famílias da área da cana para a colonização das margens da Transamazônica, como está fazendo o governo atualmente, representará o fim das tensões sociais no parque açucareiro e o verdadeiro início do Plano de Integração Nacional (FAMÍLIAS pernambucanas instalam-se na Amazônia. Jornal do Brasil, Rio de Janeiro, p. 15, 7 mai. 1971). [grifo nosso]

Compreender o problema da falta de terras no Nordeste, implica levar em conta os legados da "tradição aristocrática" do açúcar, que gerou alta concentração fundiária e tão logo fomentou disputas pela terra. Essas

\footnotetext{
12 Veja o SUPLEMENTO Especial do Jornal do Brasil, Novembro de 1971, p. 13. Publicidade do Banco do Brasil se comparando aos Bandeirantes por investir na colonização e ocupação da Amazônia de forma pioneira.
} 
disputas, com destaque para as ações lideradas pelas Ligas Camponesas ${ }^{13}$ no século $X X$, geravam grandes tensões que, na Ditadura Militar, provocaram o aparato repressivo dos militares sob a disposição do Conselho de Segurança Nacional. Assim, o que foi denominado de Reforma Agrária aparecia submetida aos imperativos da Ditadura Militar. A questão não era democratizar o acesso à terra, e sim desmobilizar os conflitos sociais, além de promover os deslocamentos de grupos populacionais em prol do objetivo governamental de ocupação dos espaços amazônicos, para sua exploração.

De acordo com Ianni (1979), esse processo encabeçado pelos militares deve ser entendido como uma contrarreforma agrária, pois se sustentava nas instituições militares. Por outro lado, Martins (1984) demonstra quão paradoxal é a colonização na Amazônia, visto que na publicidade da "terra para todos" veiculava-se a imagem da democratização da terra com base no apoio e nas práticas militares, como as de vigilância da ocupação de terras em áreas de projetos de colonização, prática sugerida pelo próprio INCRA (GOMES; GUIMARÃES NETO, 2018; ZART, 1998).

Assim, o problema da concentração fundiária era apresentado pelo seguinte discurso

[...] o presidente do órgão, Sr. José Francisco de Moura Cavalcanti, disse que o problema do campo [conflitos pela posse da terra] 'precisa ser vencido para que o Brasil ocupe o lugar que merece entre as grandes nações do mundo'. Disse em seguida, que o problema da terra no Brasil é complexo, dadas as próprias dimensões do país. Citou como exemplo disso o minifúndio no Sul e no Nordeste e os espaços vazios da Amazônia. 'Como bem disse o presidente Médici, em oportunidade feliz que não custa relembrar: somos um país de homens sem terra e terras sem homens' (INCRA faz um ano e quer resolver problemas. Jornal do Brasil, Rio de Janeiro, 10 jul. 1971.).

A referida "terra sem homens" era sobretudo das nações indígenas do Brasil, questão que não foi de forma nenhuma respeitada, como demonstra

13 Ver Porfírio (2009). 
a matéria do mesmo jornal, do dia 31/10/1970 "Bandeira de Melo defende aculturação do índio para integrá-lo à comunidade"

O presidente da Funai, General Bandeira de Melo, afirmou ontem, ao encerrar o curso-piloto de Indigenismo, que a aculturação indígena deve se processar de maneira a integrar o índio 'na nossa comunidade, pois a sociedade brasileira é muito aberta, o que facilitará a eliminação da diferença entre comunidade moderna e tribal' (BANDEIRA de Melo defende aculturação do índio para integrá-lo à comunidade. Jornal do Brasil, Rio de Janeiro, p. 8, 31 out. 1970).

Os excertos apresentados acima permitem identificar a racionalidade que orientava as práticas governamentais da Ditadura Militar de 1964-85. O discurso governamental buscava positivar suas ações a partir de jogos linguísticos que produzissem efeitos de poder. Sempre que se falava em colonização da Amazônia, impunha-se o discurso sobre desenvolvimento, lucros e progresso que se podia obter com base em várias estratégias, especialmente os incentivos fiscais para colonização de áreas supostamente vazias. Não se dissociava, no discurso governamental, a expectativa desenvolvimentista do suposto reconhecimento de demandas sociais, como a Reforma Agrária, demonstrando a sujeição governamental às expectativas do grande capital.

\section{Materiais e métodos}

Esses excertos de jornais apresentados são fruto da pesquisa empreendida no âmbito do PIBIC 2017-2018, na qual tivemos por objetivo somar aos estudos já existentes sobre a temática da Ditadura Militar. A seleção documental foi realizada na Hemeroteca Digital (BIBLIOTECA NACIONAL, 2018), plataforma online da Biblioteca Nacional, na qual consta um grande acervo de jornais, periódicos e revistas de diversos períodos da História do Brasil, onde pudemos acessar o Jornal do Brasil, de grande circulação no país.

Este periódico de publicação diária foi selecionado por abrir a possibilidade de compreender como era narrada a realidade sobre o Norte e 
Nordeste, que sugeria um território passível de intervenção. A análise priorizou narrativas dispostas no campo da imprensa entre os anos de 1970 a 1974 sobre a questão da Integração Nacional, mais especificamente sobre os progressos do Programa de Integração Nacional (PIN), a construção discursiva das "verdades" sobre o Nordeste - como a seca - e sobre o encorajamento da população para deslocar-se aos núcleos de colonização na Amazônia, ponto fundamental para a integração nacional. Estes núcleos resolveriam os imperativos militares de desenvolvimentismo e segurança nacional, tanto pela exploração da mão de obra dos migrantes, como pela ocupação de "espaços vazios", respectivamente.

Tais imperativos adquiriram estatuto governamental e se materializaram de forma exemplar no Plano de Integração Nacional (PIN), instituído na forma de decreto-lei em 16 de julho de 1970, pelo general presidente Emílio Garrastazu Médici. Este Plano era baseado em estratégias geopolíticas e tinha como objetivo a integração e valorização do imenso território amazônico, relatado como economicamente inexplorado. Entre seus objetivos constava também garantir a inviolabilidade das fronteiras e colonizar a Amazônia, questão que orientou a abertura de grandes rodovias, como a Transamazônica, e sua colonização estratégica.

A colonização era assegurada por núcleos de colonização criados para receber os migrantes, submetidos ao Instituto de Colonização e Reforma Agrária (INCRA), reestruturado dos antigos Instituto Brasileiro de Reforma Agrária (IBRA) e do Instituto Nacional de Desenvolvimento Agrário (INDA). Autarquias governamentais atreladas a importantes setores da política ${ }^{14}$, que prescreviam normas para acesso à terra nos núcleos de colonização na Amazônia sob o discurso da Reforma Agrária (SOUZA, 2019).

Reformado sob a alegação de simplificar sua estrutura administrativa, o INCRA atuava em conjunto com as iniciativas privadas de colonização como, por exemplo, a colonizadora "Integração, Desenvolvimento e Colonização" (INDECO), em Mato Grosso, denunciada mais de uma vez por violência contra trabalhadores nas suas terras ${ }^{15}$. O INCRA garantia

14 Como o Ministério do Desenvolvimento, da Integração Nacional e da Agricultura.

15 VIOLÊNCIA mata 300 garimpeiros. Jornal do Brasil, Rio de Janeiro, p. 32, 9 dez. 1979. 
facilidades de financiamento às colonizadoras, fiscalização selecionada, incentivos fiscais e venda de terras de domínio público para o privado, com valores extremamente baixos. Tais análises já foram trilhadas pela orientadora deste trabalho, a historiadora Regina B. Guimarães Neto, e por outros estudiosos.

A imprensa emergiu na análise proposta para compreender em quais medidas este importante lugar de produção de novas percepções sociais compartilhava enquadramentos interpretativos ${ }^{16}$ com o governo. Temas como a Reforma Agrária, violência no campo, os significados positivos das ações policiais eram especiais e nos dão pistas sobre os enquadramentos seletivos para a produção de verdades. Desse modo, prestava-se ao serviço de ser, em termos gerais, um dispositivo multiplicador das expectativas e discursos do estado ditatorial-militar brasileiro, com base em sua pretensa neutralidade. Agia no sentido de mobilizar a população - peça importante para a realização das ações militares no contexto da ditadura - embora, não seja abertamente declarada desta maneira.

Nesta direção, pode-se refletir os métodos que a História dispõe para mostrar especificidades temporais. É uma ciência que produz a inteligibilidade do que é aparentemente ininteligível e comporta a análise da escrita como discurso (CERTEAU, 2000, p. 91-100). Nas pesquisas realizadas, foi possível compreender como práticas que se mostram "inocentes" ou neutras (o discurso jornalístico, por exemplo) contribuíram para a positivação da ação estatal frente à violação dos direitos humanos, importante para que alunos da Educação Básica possam treinar o olhar para a avalanche diária de informações. A relação da imprensa com instâncias governamentais permite identificar a especificidade temporal do problema ora exposto e inscrevê-lo no macrocosmo das tecnologias da exploração do trabalho e da violência, num contexto de curta, média e longa duração, resguardadas suas especificidades.

Assim, a narrativa histórica permite dizer, na dimensão do acontecido, o encadeamento de evidências que são simuladas como desconexas, mas que obedecem a uma racionalidade. Nesta medida, o

16 Ver BUTLER, Judith (2016). 
trabalho seguiu reflexões metodológicas e epistemológicas ${ }^{17}$ fundamentadas numa escrita competente da História para que, assim, a narrativa produza o efeito de ser contra a História Universal e exercida "contra a corrente" (REIS, 2006, p. 44). Assim, que a História não seja uma crônica abstrata.

Desnaturalizar ${ }^{18}$ os sentidos da ditadura militar é prática que se torna possível através do cruzamento de fontes selecionadas da imprensa. Nesta medida, também é possível articular estratégias de ensino que lutem contra histórias pobres de atributos conceituais. Ao estudar o período da ditadura militar, a pesquisa sobre a imprensa mostra-se importante aliada para a prática docente. Isto por ser um mecanismo que apresenta indícios da multiplicação e execução dos objetivos militares ao naturalizar e partilhar binarismos, do tipo "atraso-desenvolvimento", "ordem-desordem", "segurança-subversão" etc.

Importa ainda refletir a respeito de uma dimensão histórica que discuta a política, não de forma a glorificar seus feitos e tomar as nações como figuras ilustres, mas em tematizar a política como produtora de vulnerabilidade no seio de seu próprio dispositivo legislativo e executivo.

\section{Resultados e discussão}

A propaganda governamental, para controle e uso do território brasileiro e manipulação da população, fez compreender que havia um projeto articulado para as famílias que se instalassem na Amazônia. No entanto, o discurso governamental não deixava claro os resultados da colonização, nem as condições de trabalho às quais eram submetidos os migrantes.

$\mathrm{Na}$ racionalidade governamental, a penetração e colonização do território amazônico significava garantia de segurança nacional e desenvolvimento das condições de produção econômica do país, sob o discurso da Reforma Agrária e do progresso. Na prática, a colonização dessa área tinha caráter experimental. Gomes e Guimarães Neto (2018), a partir

\footnotetext{
17 Ver Farge (2011), Certeau (2000), Foucault (2008) e Ricoeur (2007).

18 Ver os textos de Montenegro (2010).
} 
dos relatos de trabalhadores, demonstram o despreparo de órgãos do governo, como o INCRA, para definição do tipo de lavoura a ser desenvolvida, o que redundou em ruína e sujeição ao trabalho degradante para pequenos proprietários que investiram em lotes de terra na Amazônia.

$\mathrm{Na}$ imprensa também é fácil encontrar denúncias da Comissão Pastoral da Terra sobre a exploração do trabalho, violação de direitos básicos e de massacres, como na seguinte reportagem:

A morte de cerca de 300 garimpeiros vítimas das violências na área da Colonizadora INDECO em Alta Floresta, Mato Grosso, denunciada pela Comissão Pastoral da Terra não é recente e se circunscreve no quadro geral da penetração do grande capital na região central do Brasil. A CTP recebeu, em setembro passado, a denúncia de torturas e assassínios na área da colonização. Desde então, a comissão esteve no local verificando e constatando a veracidade das denúncias, agora tornadas públicas. A violência na área é generalizada pelos jagunços do latifundiário Ariosto da Riva, proprietário da Colonizadora INDECO e responsável pelo massacre naquela localidade. (VIOLÊNCIA mata 300 garimpeiros. Jornal do Brasil, Rio de Janeiro, p. 32, 9 dez. 1979).

Assim, com base na historiografia e nos documentos utilizados, é possível visualizar a perfomatividade do aparato jurídico, ao inscrever e suspender a lei e a ordem quando conveniente, frequentemente ignorando a questão social do trabalho, facilmente flagrado em situação degradante (GOMES; GUIMARÃES NETO, 2018). Nesse quadro, também mencionamos a questão da violência contra trabalhadores do campo e indígenas, as práticas de vigilância dos órgãos de informação, e a associação entre o governo federal e a iniciativa privada para conformar um modelo de exploração econômica baseado na riqueza gerada pela propriedade da terra. Enfim, atributos importantes para compreendermos a materialidade das práticas governamentais militares no período de 1964-1985, que contaram com o comprometimento político e econômico de setores da imprensa para fazer a população participar do jogo do poder.

O Estado organiza uma narrativa para legitimar suas ações. Tudo está dito, mas de forma a neutralizar a materialidade da dominação e a 
ação das pessoas, porque não é de interesse do governo que as pessoas se rebelem. A dominação funciona melhor quando as pessoas dizem "sim", no lugar de se sentirem obrigadas ou violentadas, como demonstram importantes estudos no campo das tecnologias do poder. Mas, no conjunto, a violência física impera.

Partimos da premissa de que não há nada a ser revelado com este estudo, mas, sim, desnaturalizado. Na História, as coisas estão, sobretudo, ditas. Os jornais dizem exatamente o que querem, as respostas aqui apresentadas respondem às seguintes perguntas: o que dizem? Como dizem? Quais palavras estão em circulação? Quais condições históricas que permitem que determinadas coisas sejam ditas e provoquem estas ou aquelas reações?

Cabe, assim, ao historiador e ao educador se preocuparem em desnaturalizar os sentidos que são postos. A imprensa e a escola se encontram no fluxo da circulação de notícias e ideias, as quais são selecionadas para integrar um discurso. Esta ação, que se apresenta em lugares institucionais e empresas midiáticas, permite a replicação do poder e mostra-se eficiente por produzir outras percepções.

Neste caminho, ao serem estabelecidas formas de apresentação e 'esclarecimento', lembramos as reflexões de Foucault (1996, p. 9) em $A$ Ordem do Discurso:

[...]a informação é selecionada, organizada e redistribuída por certo número de procedimentos que têm por função conjurar seus poderes e perigos, dominar seu acontecimento aleatório, esquivar sua pesada e temível materialidade.

Concluímos que o discurso da imprensa e da escola são engendrados por formas de racionalidade que podem ser traduzidas enquanto dispositivos políticos ${ }^{19}$, formadores de opiniões e verdades. As escolas, assim como a imprensa, não são neutras. Há um aparato escolar e midiático que insiste na produção da ignorância, desinformação e sujeição da sociedade a determinadas formas de poder. Isto reflete no tipo de

19 Ver Revel (2005). 
cidadão "educado" que sai das instituições escolares ${ }^{20}$. Portanto, é fundamental que a prática docente esteja investida por consciência histórica para desprogramação da ordem do progresso.

Este tempo, de massificação da comunicação e da produção de informações em tempo real, é uma realidade que deve ser pensada pela atividade do professor. Esta realidade é decisiva para que os rastros marcados na imprensa sejam utilizados em sala de aula, ensinando a interpretar o lugar de onde se produzem discursos, a atualidade e, ao mesmo tempo, a ação de ensinar e fazer História.

\section{Referências}

ARRIADA, Eduardo; VALLE, Hardalla; CLARO, Lisiane. A utilização de fontes no ensino de história: a imprensa na construção do conhecimento. Revista Momento, Rio Grande, v. 20, p. 59-72, 2011.

BANDEIRA de Melo defende aculturação do índio para integrá-lo à comunidade. Jornal do Brasil, Rio de Janeiro, p. 8, 31 out. 1970.

BENJAMIN, Walter. Teses sobre o conceito de História. In: BENJAMIN, Walter. Obras Escolhidas: magia e técnica, arte e política. São Paulo: Editora Brasiliense, 1985. v. 1, cap. 15, p. 222-234.

BIBLIOTECA NACIONAL (Brasil). Hemeroteca digital. 2018. Disponível em: http://bndigital.bn.gov.br/hemeroteca-digital/. Acesso em: 20 mai. 2018.

BITTENCOURT, Circe. Livros didáticos entre textos e imagens: o saber histórico na sala de aula. São Paulo: Contexto, 2009.

BLOCH, Marc. Apologia da história ou o ofício do historiador. Rio de Janeiro: Jorge Zahar Ed, 2001.

BRASIL. Secretaria de Educação Fundamental. Parâmetros Curriculares Nacionais de História. Brasília: MEC: Secretaria da Educação, 1998.

\footnotetext{
20 Veja os dados: PALHARES, Isabela; DIÓGENES, Juliana. Três em cada 10 brasileiros são analfabetos funcionais no País. O Estado de São Paulo, São Paulo, 6 ago. 2018. Disponível em: $\quad$ https://educacao.estadao.com.br/noticias/geral,tres-em-cada-10-sao-analfabetosfuncionais-no-pais,70002432924. Acesso em: 29 nov. 2018;

TRÊS em cada 10 brasileiros são analfabetos funcionais. Educação, São Paulo, 8 ago. 2018a. Disponível em: https://revistaeducacao.com.br/2018/08/08/tres-em-cada-10brasileiros-sao-analfabetos-funcionais-1/. Acesso em: 29 nov. 2018;

TRÊS em cada dez são analfabetos funcionais no país, mostra estudo. Veja, São Paulo, 6 ago. 2018b. Disponível em: https://veja.abril.com.br/educacao/tres-em-cada-dez-saoanalfabetos-funcionais-no-pais-mostra-estudo/. Acesso em: 29 nov. 2018.
} 
BUTLER, Judith. Quadros de guerra: quando a vida é passível de luto. 2. ed. Rio de Janeiro: Civilização Brasileira, 2016.

CAPELATO, Maria Helena Rolim. Imprensa e história do Brasil. São Paulo: Contexto, 1988. 78 p. (Coleção Repensando a História)

CERTEAU, Michel de. A Escrita da história. Rio de Janeiro: Forense Universitária, 2000.

DELFIM Netto defende a integração. Jornal do Brasil, Rio de Janeiro, p. 1, 17 jul. 1970.

FAMÍLIAS pernambucanas instalam-se na Amazônia. Jornal do Brasil, Rio de Janeiro, p. 15, 7 maio 1971.

FARGE, Arlette. Lugares para a história. São Paulo: Autêntica, 2011. 135 p.

FARIA, Maria Alice. Como usar o jornal na sala de aula. 10. ed. São Paulo: Contexto, 2009. 162 p.

FARIA, Maria Alice. O jornal na sala de aula. 13. ed. São Paulo: Contexto, 2004. 128 p.

FARIA, Maria Alice; ZANCHETTA JÚNIOR, Juvenal. Para ler e fazer o jornal na sala de aula. 2. ed. São Paulo: Contexto, 2005. 178 p.

FONSECA, Selva Guimarães. Didática e prática de ensino de história. Campinas, SP: Papirus, 2003.

FOUCAULT, Michel. A Ordem do discurso. São Paulo: Edições Loyola, 1996.

FOUCAULT, Michel. Microfísica do poder. Rio de Janeiro: Edições Graal, 2008.

GENERAL vê Amazônia sob ameaça. Jornal do Brasil, Rio de Janeiro, p. 4, 14 ago. 1971.

GOMES, Ângela de Castro; GUIMARÃES NETO, Regina Beatriz. Trabalho escravo contemporâneo: tempo presente e usos do passado. Rio de Janeiro: FGV, 2018.

GUIMARÃES NETO, Regina Beatriz. A lenda do ouro verde: política de colonização no Brasil contemporâneo. Cuiabá: Ed. Unicem, 2002. (Apoio Unesco).

HABERMAS, Jügen. $O$ discurso filosófico da modernidade. São Paulo: Martins Fontes, 2000. 540 p.

HARTOG, François. Regimes de historicidade: presentismo e experiências do tempo. São Paulo: Autêntica, 2013. 267 p. 
IANNI, Octavio. Colonização e contrarreforma agrária na Amazônia. Petrópolis, RJ: Vozes, 1979

INCRA faz um ano e quer resolver problemas. Jornal do Brasil, Rio de Janeiro, 10 jul. 1971.

LUCA, Tania Regina de. Fontes impressas: história dos, nos e por meio dos periódicos. In: PINSKY, Carla Bassanezi (org.). Fontes Históricas. São Paulo: Contexto, 2005. p.111- 153.

MARTINS, José de Souza. A militarização da questão agrária no Brasil. Petrópolis, RJ: Vozes, 1984.

MENESES, Sônia. A Operação Midiográfica: da escritura do evento na cena pública à Inscrição do acontecimento no tempo - a mídia, a memória e a história. In: ALMEIDA, Lucila; FERREIRA, Marieta. História do tempo presente. Rio de Janeiro: FGV Editora, 2014. p. 231-257.

MISSÃO Histórica. Jornal do Brasil, Rio de Janeiro, p. 1, 31 out. 1974.

MONTENEGRO, Antônio Torres. História, metodologia e memória. São Paulo: Ed. Contexto, 2010.0

NIETZSCHE, Friedrich. Segunda consideração intempestiva: a utilidade e o inconveniente da história para a vida. São Paulo: Escala, 2008. 125 p.

PALHARES, Isabela; DIÓGENES, Juliana. Três em cada 10 brasileiros são analfabetos funcionais no País. O Estado de São Paulo, São Paulo, 6 ago. 2018. Disponível em: https://educacao.estadao.com.br/noticias/geral,tresem-cada-10-sao-analfabetos-funcionais-no-pais,70002432924. Acesso em: 29 nov. 2018

PORFÍRIO, Pablo F. de A. Medo, comunismo e revolução: Pernambuco (1959-1964). Recife: Ed. UFPE, 2009.

REIS, José Carlos. História e teoria: historicismo, modernidade, temporalidade e verdade. 3. ed. Rio de Janeiro: FGV Editora, 2006. 246 p.

REVEL, Judith. Foucault: conceitos essenciais. São Carlos: Claraluz, 2005. $93 \mathrm{p}$.

RICOEUR, Paul. A memória, a história, o esquecimento. Campinas, SP: Editora da Unicamp, 2007.

SELEÇÃO se exibirá em homenagem à Revolução. Jornal do Brasil, Rio de Janeiro, p. 26, 26 fev. 1970.

SOUZA, Jonathas Duarte Oliveira. Tecnologias de poder e controle da questão agrária brasileira: o INCRA e a SUDAM. In: SIMPÓSIO NACIONAL DE HISTÓRIA, 30., 2019, Recife. Anais [...]. Recife: ANPUH, 2019. 
TRÊS em cada 10 brasileiros são analfabetos funcionais. Educação, São Paulo, 8 ago. 2018a. Disponível em: https://revistaeducacao.com.br/2018/08/08/tres-em-cada-10-brasileirossao-analfabetos-funcionais-1/. Acesso em: 29 nov. 2018

TRÊS em cada dez são analfabetos funcionais no país, mostra estudo. Veja, São Paulo, 6 ago. 2018b. Disponível em: https://veja.abril.com.br/educacao/tres-em-cada-dez-sao-analfabetosfuncionais-no-pais-mostra-estudo/. Acesso em: 29 nov. 2018

VIOLÊNCIA mata 300 garimpeiros. Jornal do Brasil, Rio de Janeiro, p. 32, 9 dez. 1979.

ZART, Laudemir Luiz. Desencanto na nova terra: assentamento no município de Lucas do Rio Verde MT na década de 80. 1998. 189p. Dissertação (Mestrado em Sociologia Política) - Universidade Federal de Santa Catarina, Florianópolis, 1998.

Recebido em 05 de fevereiro de 2019

Aceito em 23 de novembro de 2019 